\title{
Next Generation Cereal Crop Yield Enhancement: From Knowledge of Inflorescence Development to Practical Engineering by Genome Editing
}

\author{
Lei Liu, Penelope L. Lindsay (1) and David Jackson * \\ Cold Spring Harbor Laboratory, Cold Spring Harbor, NY 11724, USA; 1liu@cshl.edu (L.L.); \\ lindsay@cshl.edu (P.L.L.) \\ * Correspondence: jacksond@cshl.edu
}

check for updates

Citation: Liu, L.; Lindsay, P.L.; Jackson, D. Next Generation Cereal Crop Yield Enhancement: From Knowledge of Inflorescence Development to Practical Engineering by Genome Editing. Int J. Mol. Sci. 2021, 22, 5167. https:// doi.org/10.3390/ijms22105167

Academic Editors: Ki-Hong Jung and Jae-Yean Kim

Received: 1 April 2021

Accepted: 10 May 2021

Published: 13 May 2021

Publisher's Note: MDPI stays neutral with regard to jurisdictional claims in published maps and institutional affiliations.

Copyright: (C) 2021 by the authors Licensee MDPI, Basel, Switzerland This article is an open access article distributed under the terms and conditions of the Creative Commons Attribution (CC BY) license (https:/ / creativecommons.org/licenses/by/ $4.0 /$ )

\begin{abstract}
Artificial domestication and improvement of the majority of crops began approximately 10,000 years ago, in different parts of the world, to achieve high productivity, good quality, and widespread adaptability. It was initiated from a phenotype-based selection by local farmers and developed to current biotechnology-based breeding to feed over 7 billion people. For most cereal crops, yield relates to grain production, which could be enhanced by increasing grain number and weight. Grain number is typically determined during inflorescence development. Many mutants and genes for inflorescence development have already been characterized in cereal crops. Therefore, optimization of such genes could fine-tune yield-related traits, such as grain number. With the rapidly advancing genome-editing technologies and understanding of yield-related traits, knowledge-driven breeding by design is becoming a reality. This review introduces knowledge about inflorescence yieldrelated traits in cereal crops, focusing on rice, maize, and wheat. Next, emerging genome-editing technologies and recent studies that apply this technology to engineer crop yield improvement by targeting inflorescence development are reviewed. These approaches promise to usher in a new era of breeding practice.
\end{abstract}

Keywords: crop-yield improvement; breeding; inflorescence development; genome editing

\section{Introduction}

The global population is expected to increase to 9.2 billion in 2050, and agricultural production needs to increase by about 70 percent from current levels to meet the increased food demand, as predicted by Food and Agriculture Organization (http:/ /www.fao.org / wsfs / forum2050/wsfs-background-documents/issues-briefs/en/, accessed on 1 February 2021). Cereal crops, such as rice, wheat, and maize, are the world's most important sources of calories for humans, livestock feed for animals, and raw material for biofuel [1]. However, with the threat of urbanization, land erosion, sea-level rise, and pollution, the arable land for cereal-crop production will become more limited [2]. Therefore, improving cereal-crop-grain production is critical to meet further demand.

A majority of modern crop varieties were domesticated from their wild ancestors within the past $\sim 12,000$ years [3]. During domestication, plants were selected to render them easier to breed, culture, harvest, and store seeds [4]. In the past century, domesticated crops underwent improvement to achieve high productivity and widespread adaptability, by pyramiding beneficial mutations and recombinants in key genes [5]. Adopting new technologies, such as hybrid breeding, high-yielding dwarf wheat and rice varieties, and genetic modification by transformation, the grain yield of cereal crops has risen steadily [4-6]. Nowadays, rice, wheat, and maize supply nearly half of the calories consumed by humans, suggesting that their production is critical to feed an increasing population [1].

Dissecting the genetic changes during crop domestication and improvement is critical to understand the mechanistic basis of grain yield, and to guide breeding efforts towards 
developing high-yielding varieties [1]. Grain yield of cereal crops is a complex trait controlled by numerous quantitative trait loci (QTL). Current crop yield enhancement relies heavily on natural genetic changes $[4,5]$. Great progress has been made in mapping and cloning these yield-related QTLs in crops [7-14]. However, a majority of natural variants underlying yield-related traits have a minor effect, and those that have a greater effect may act only in specific genetic backgrounds [7-14], challenging their application in yield enhancement. On the other hand, climate change is spurring extreme environmental conditions, including drought, heat, cold, saline, and alkaline soils [2]. Therefore, geneticists and breeders face the challenge of enhancing the yield of cereal crops through genetic improvement of germplasm to bridge the gap between production and demand [2].

For most cereal crops, yield relates to grain production. Increasing grain number and weight are two important paths to increase yield per plant $[10,11,14]$. Grain number is determined during inflorescence development [12-15], and mutants and genes affecting this process have already been well studied in crops such as rice and maize [8,12-15]. Recent studies suggest that we can create new beneficial alleles by genome editing to optimize the expression or function of these genes. Indeed, some of these new alleles may have a larger effect than natural alleles [16-20]. These findings suggest that applying the knowledge of crop inflorescence development can help to engineer crop yield improvement, and usher in a new era of breeding practice. In this review, we focus on crop inflorescence development in rice, wheat and maize (Figure 1), and how to use this knowledge to improve yield by increasing grain number. We also touch upon emerging technologies to efficiently genome edit diverse germplasm. 


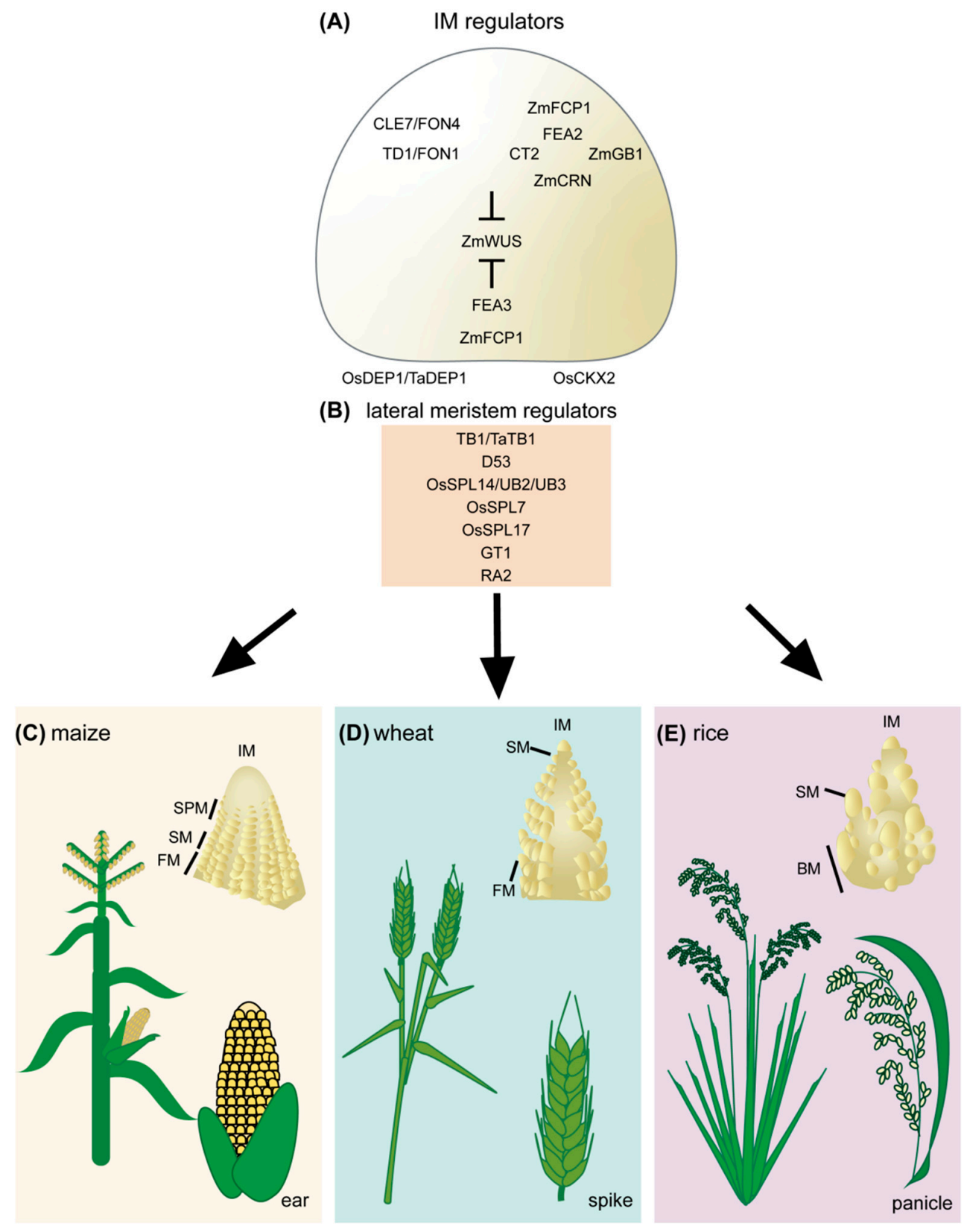

Figure 1. Regulators of cereal inflorescence development. (A) Inflorescence meristem regulators include the receptor and receptor-like proteins TD1/FON1, FEA2, and FEA3. These proteins perceive secreted CLE peptides, including ZmCLE7/FON4 and ZmFCP1. Perception of CLE peptides restricts ZmWUS activity. Downstream signaling components of FEA2 include CT2, ZmCRN, and ZmGB1. The rice DEP1 G protein also contributes to inflorescence meristem regulation through OsCKX2, though it is unclear if it acts in the CLV signaling pathway. (B) Lateral meristem regulators include TB1/TaTB1, D53, OsSPL14/UB2/UB3, OsSPL7, OsSPL17, GT1, and RA2. Inflorescence development and architecture of maize (C), wheat (D), and rice (E). IM, inflorescence meristem; SPM, spikelet pair meristem; SM, spikelet meristem; FM, floral meristem; BM, branch meristem.

\section{Grain Number Is Determined during Inflorescence Development in Cereal Crops}

Grains or kernels grow on the panicle in rice, and the spike in wheat, barley and maize. These are the two typical inflorescence architectures in cereal crops [21,22], and they differ in branching architecture, as the panicle has both long and short branches, while the spike has only short branches [21,22]. Unlike rice and wheat, modern maize produces two distinct inflorescences, the tassel and ear [15]. The tassel bears staminate flowers and is borne at the apex of the mature plant, whereas the ear bears pistillate flowers 
to form kernels [15]. In this review, we only discuss the ear inflorescence in maize. The inflorescence stem is called the rachis, with a series of nodes that produce additional long branches or short branches (spikelets) [21]. In the rice panicle, the rachis can produce primary and secondary branches in a spiral phyllotaxy and bears single spikelets [21,22]. The rachis produces only a series of short branches in the wheat and maize spike, called spikelets $[14,15]$. However, the panicle and spike have a similar fundamental development. After the transition from the vegetative phase to the reproductive phase, the vegetative shoot apical meristem (SAM) transitions into the inflorescence meristem (IM) in rice and wheat, and the axillary meristems in leaf axils form the ear IM in maize [14,15]. Each IM will further proliferate to initiate branch meristems (BM) and spikelet meristems (SM) in rice, but only SMs in wheat [14,15]. In maize, the ear IM initiates spikelet pair meristems (SPM) and each SPM forms two SMs [14,15]. Each SM will further develop into floret meristems (FM) that give rise to grains after fertilization $[14,15]$. Therefore, the total number of SMs generated by the IM determines the number of grains on each panicle and spike, suggesting IM activity is critical for the grain number and yield (Figure 1).

The strategies for increasing grain numbers on panicles and spikes may differ depending on the species. As the panicle has long branches, an increase in grain number could be achieved by promoting the IM to develop more BM and/or SM. In contrast, increasing grain number on cereals that make a spike can only be achieved by promoting SM development. Knowledge of the genetic regulation of inflorescence architecture can help understand the basic developmental mechanisms to optimize cereal inflorescence architecture. Studies of mutants and quantitative genetic analyses have already characterized many genes and pathways that play a critical role in inflorescence development [7-15]. The conserved function of critical genes across species can facilitate understanding of inflorescence development, and guide yield enhancement in other agronomically important cereal species, such as orphan crops [14]. In the following section, we introduce some essential genes and pathways that regulate inflorescence development across rice, maize and wheat, focusing on regulation of IM activity and axillary meristem formation (Figure 1).

\section{CLAVATA-WUSCHEL (CLV-WUS) Negative Feedback Loop Maintains IM Activity}

Meristem size and the number of branches relies on IM activity, which is maintained by the CLAVATA (CLV)-WUSCHEL (WUS) feedback signaling pathway, which was first discovered in Arabidopsis [23]. This pathway is functionally conserved in eudicots and in grasses, such as rice and maize. In this pathway, a homeodomain transcription factor, WUS, is expressed in the meristem organizing center and coordinates meristem activity by activating expression of the secreted peptide CLV3, which binds its receptor, CLV1 to repress WUS expression [24-29]. CLV orthologs in maize include the CLV1 ortholog THICK TASSEL DWARF1 (TD1) [30], and CLV3 ortholog ZmCLAVATA3/EMBRYO SURROUNDING REGION-RELATED7 (ZmCLE7) [31,32], as well as a second CLE peptide, ZmFON2-LIKE CLE Protein1 (ZmFCP1) [33], which acts in a distinct CLV pathway to repress WUS expression. Besides the CLV1 receptor, another LRR receptor-like protein FASCIATED EAR3 (FEA3) represses WUS from below a region of the meristem known as the organizing center, by perceiving ZmFCP1 [33]. The CLV2 ortholog in maize, FASCIATED EAR2 (FEA2), transmits signals from ZmCLE7 and ZmFCP1 through two different candidate downstream effectors, the maize heterotrimeric $G$ proteins, COMPACT PLANT2 (CT2) and ZmGB1, and CORYNE (ZmCRN) [34-37]. Null mutants of these CLV genes cause meristem over-proliferation, leading to enlarged inflorescence stems and fasciated ears in maize [30-37].

The orthologs of WUS, CLV1, and CLV3 in rice have also been identified. tillers absent1 (tab1) is a mutant in the WUS ortholog in rice, and has a flat IM, and shorter rachis branches with fewer spikelets, suggesting a role in axillary meristem initiation [37]. In contrast, the IM of rice clv1 ortholog mutant, floral organ number 1 (fon1), is larger and produces more long branches [38]. Similarly, fon4, a mutant in the CLV3 ortholog, has a more obvious enlargement in IM size and gives rise to more than one primary rachis [39]. A QTL for 
grain yield and nitrogen use efficiency was identified as a rice heterotrimeric $\mathrm{G}$ protein subunit, DENSE AND ERECT PANICLE1 (DEP1) [40,41]. A gain-of-function mutant of $D E P 1$ has a larger IM, and produces more long branches by enhancing the expression of CYTOKININ OXIDASE 2 (OsCKX2) [40]. However, it is unclear whether DEP1 participates in the CLV-WUS signaling pathway in a manner similar to maize heterotrimeric G proteins.

The CLV-WUS signaling pathway has not been well studied in wheat. However, the ortholog of rice heterotrimeric G-protein subunit DEP1, TaDEP1, was found to act as a negative regulator of IM activity to affect spike length and spikelet number [40]. As the CLV-WUS signaling pathway function is conserved across many plant species, it is expected to have a similar role in wheat.

\section{The Regulation of Lateral Meristem Initiation}

After the transition from the vegetative meristem to the IM, the IM will proliferate to generate daughter stem cells that form new meristems called axillary or lateral meristems $[14,15,21]$. In a panicle, two types of lateral meristems, BM and SM, are formed and develop into long and short branches, respectively $[14,15,21]$, whereas, only SMs are generated on a spike $[14,15,21]$. Therefore, axillary lateral meristems initiate the development of long branches and spikelets. In rice and wheat, inflorescence branching usually correlates with vegetative shoot branching, also called tillering. Tillering is suppressed in domesticated maize, and was achieved through selection for a gain-of-function allele of the TCP (TEOSINTE BRANCHED1, CYCLOIDEA, PCF1) transcription factor TEOSINTE BRANCHED1 (TB1) to increase apical dominance compared to its wild ancestor teosinte $[14,15,21,42]$. A comprehensive study by ChIP-seq, RNA-seq, and hormone and sugar measurements reveals that TB1 may regulate phytohormone pathways such as gibberellins, abscisic acid and jasmonic acid, as well as sugar metabolites for energy balance [43]. TB1 orthologs in rice and wheat function similarly to negatively regulate both tillering and inflorescence branching [44,45].

In rice, OsTB1 is directly regulated by IDEAL PLANT ARCHITECTURE1 (IPA1), a SQUAMOSA PROMOTER BINDING PROTEIN-BOX-LIKE (SPL) transcription factor (OsSPL14), which is critical in regulating rice vegetative and inflorescence architecture, and substantially enhances grain yield [46-48]. IPA1 regulation involves miRNAs miR156 and miR529 [46,47]. A beneficial IPA1 allele has a point mutation in the miR156 target site, perturbing regulation by this miRNA leading to upregulation of OsSPL14 [46]. This upregulation suppresses tillering and increases the number of vascular bundles, which may contribute to water/nutrient transport and lodging resistance, and an increase in grain yield [46]. IPA1 acts as a direct downstream component of DWARF53 (D53) signaling to affect strigolactone (SL)-induced gene expression [49]. D53 is a key repressor of the SL signaling pathway, and strigolactones are mobile root-to-shoot phytohormones that suppress shoot branching by inhibiting the outgrowth of axillary buds [48]. D53 and IPA1 proteins interact to suppress the transcriptional activation activity of IPA1 [49]. Meanwhile, IPA1 binds directly to the D53 promoter and functions in feedback regulation of SL-induced D53 expression [49]. As well as OsSPL14, OsSPL7 and OsSPL17 are also negative regulators of tillering, but positive regulators of the spikelet transition [50]. Fine-tuning the expression of these OsSPLs by miR156 and miR529 can optimize panicle size and yield [50].

The OsSPL14 orthologs in maize, UNBRANCHED2 (UB2) and UB3, redundantly limit the rate of cell differentiation in the lateral domains of meristems [51]. Remarkably, a kernel row number (KRN) QTL, KRN4, maps to a $\sim 3 \mathrm{~Kb}$ intergenic region about $60 \mathrm{~Kb}$ downstream from $U B 3$, and interacts with the $U B 3$ promoter to quantitatively enhance UB3 expression and KRN $[52,53]$. This chromatin-based interaction of KRN4 with the UB3 promoter is mediated by UB2 [53]. Thus, UB3 negatively regulates IM size and spikelet number in maize [51-53]. Overexpression of maize UB3 in rice has a dosage-dependent effect on panicle branch number and grain yield [54]; UB3 expression promotes grain yield, but high expression suppresses plant growth and reduces yield [54]. 
Consistent with its function in rice, overexpression of miR156 in wheat leads to increased tiller number and severe defects in spikelet formation, probably due to repression of a group of SPL genes [55]. Strigolactone signaling repressor TaD53 also directly interacts with the N-terminal domains of TaSPL3/17, suggesting association between miR156-TaSPLs and SL signaling pathways during wheat tillering and spikelet development similar to in rice [55].

The SMs are paired in maize, and single in wheat and rice [15]. However, a mutation in TaTB1 converts single to paired spikelets in modern bread wheat cultivars, and increases spikelet number [45]. Variation in spikelet row-type is also studied in barley, which is in the same Triticeae tribe and has an unbranched spike inflorescence similar to wheat. Each rachis internode in barley develops one central and two lateral spikelets [56]. In two-rowed varieties, the central spikelet is fertile and produces grain, and the two lateral spikelets are sterile [56]. The TB1 ortholog in barley, INTERMEDIUM-C (INT-C), controls lateral spikelet fertility, resulting in changes from two-rowed to six-rowed varieties, where all three spikelets are fertile and develop into grains [57]. The six-rowed phenotype is controlled by several additional loci, including SIX-ROWED SPIKE1 (VRS1) [58], VRS2 [59], VRS3 [60], and VRS4 [61]. VRS3, VRS4, and INT-C act as transcriptional activators of VRS1 and control the number of fertile lateral spikelets [62]. The orthologs of VRS1 and VRS4 in maize are GRASSY TILLERS1 [63,64] and RAMOSA2 [65], which act as negative regulators of shoot and ear branching, respectively. As TB1 orthologs have a similar function in grain row formation in wheat and barley, manipulating these VRS orthologs may also increase the grain number in wheat.

\section{Optimizing Inflorescence-Development-Related Genes to Enhance Crop-Yield Traits}

Targeted genome editing is a powerful and simple tool that allows new possibilities to modify genomic sequences, accelerating gene function analysis and speeding up breeding by creating favorable alleles. The improvements in genome editing tools and transformation methods help researchers overcome the challenges of complex genomes and lack of mutants due to genetic redundancy in cereal crops. In particular, the application of clustered regularly interspaced short palindromic repeats (CRISPR)-Cas family-based technology allows the generation of mutations in almost any gene of interest. It is also possible to fine-tune function of a target gene, for example, editing key inflorescence development regulators can produce new high-yielding alleles. Next, we introduce four cases that have implemented genome editing to optimize the function of inflorescence-related genes to enhance grain yield.

\subsection{Case 1: DEP1 and IPA1 Coding Sequence Mutagenesis by CRISPR-Cas9 to Enhance Grain-Yield-Related Traits in Rice}

Mutants in DEP1 increase panicle size and grain number [40], and mutations in the miR156 cleavage site of IPA1 have "ideal plant architecture", such as fewer tillers, more grains per panicle, and sturdy stems, substantially enhancing rice grain yield [46]. Li et al. used CRISPR-Cas9 to knockout the DEP1 coding region and mutate the miR156 cleavage site in IPA1 in a single rice cultivar [66]. Two DEP1 frameshift mutations resulted in shorter plants and panicles, with more flowers per panicle [66]. An ipa1 CRISPR allele, interrupting the miR156 cleavage site, led to a decrease in tillers and increase in plant height, flower number and panicle length, similar to a previously characterized allele with a cleavage site mutation $[46,66]$. These results suggest that CRISPR-Cas9 can edit key regulators of important traits to modify these traits in cultivated rice varieties [66].

\subsection{Case 2: Producing Beneficial Promoter-Edited Alleles of OsTB1 by CRISPR-Cas9 to Enhance Grain-Yield-Related Traits in Rice}

Most 'super rice' varieties with high yields have several beneficial agronomic traits, including strong culms for lodging resistance and large panicles for high yield [20]. Cui and $\mathrm{Hu}$ et al. used a chromosome segment substitution population to map culm strength, 
by measuring the stem cross-section area (SCSA) of the fourth internode, and found that OsTB1 was the causative gene of a major QTL [20]. A TGTG insertion in the $5^{\prime}$ UTR was predicted to control OsTB1 expression, and consequently SCSA [20]. Next, the authors introduced mutations in the promoter and 5'-UTR of OsTB1 by CRISPR-Cas9 using six sgRNAs [20]. Nine different mutations were obtained, including large and small deletions and by chance one that recreated the TGTG insertion. These mutations were classified into three types, based on the effect on expression and phenotype. Type 1 alleles had large deletions covering an OsSPL14 binding site and part of the $5^{\prime}$-UTR, and these lines had lower OsTB1 expression and more tillers with smaller culms and panicles [20]. Type 2 alleles had changes in other parts of the OsTB1 promoter, and had no change in gene expression or phenotype [20]. Type 3 alleles had higher gene expression and more tillers with larger culms and panicles, and one of them had the TGTG insertion, supporting its role as a QTL [20]. Therefore, CRISPR-Cas9 could produce desirable alleles with appropriate levels of expression for optimizing breeding targets [20].

\subsection{Case 3: Promoter Editing of CLE Genes and Knockout of a Redundant Paralog by CRISPR-Cas9 to Enhance Grain-Yield-Related Traits in Maize}

Null alleles of maize $c l v$ genes cause meristem over-proliferation and fasciated ears that develop many more disorganized and shorter kernel rows with low grain yield [30-37]. However, weak coding sequence alleles of fea 2 and fea 3 generated by ethyl methanesulfonate mutagenesis cause a quantitative increase in kernel row number while maintaining meristem organization and ear length, highlighting the potential to quantitatively manipulate fea genes for yield enhancement [33,37]. This idea was tested by Rodríguez-Leal et al., who generated weak alleles by CRISPR-Cas9 editing of cis-regulatory regions, such as promoters, in tomato [16]. Liu et al. tested this strategy in maize, by CRISPR-Cas9 multiplex editing of the promoters of ZmCLE7 and ZmFCP1. This produced weak alleles that maintain normal ear length but with a quantitative increase in KRN and grain yield [17]. Potential regulatory regions for editing were predicted using chromatin state (assay for transposase accessible chromatin with sequencing and micrococcal nuclease digestion with sequencing) and conserved non-coding sequence (CNS) data [17]. Promoter-edited alleles with deletions in these regions had lower ZmCLE7 and ZmFCP1 expression, leading to an increase in IM size, kernel number and grain yield [17]. In contrast to these deletion alleles, one allele in ZmCLE7 carrying an inversion produced opposite effects, decreasing kernel number and grain yield, possibly due to an expansion of ZmCLE7 expression and a decrease in meristem size and yield-related traits [17].

In addition to weak allele promoter editing, Liu et al. also explored redundant compensators of $Z m C L E 7$ through transcriptome analysis of $Z m c l e 7$ mutants. They found a previously uncharacterized maize CLE gene, ZmCLE1E5, that was upregulated in Zmcle7 mutants [17,31]. CRISPR-Cas9 edited null alleles of ZmCLE1E5 had much weaker meristem size phenotypes than Zmcle7, but significantly enhanced it [17]. The Zmcle1e5 null alleles also quantitatively enhanced grain-yield-related traits, such as KRN and grain yield per ear [17]. The three CLE genes edited in this study had not been previously linked to yield-related QTLs in maize diversity populations, and ZmCLE7 regulatory regions have low genetic variation [17]. Thus, CRISPR-Cas9 genome editing produced new beneficial maize alleles, even for genes not previously associated with yield traits, and had effects greater than molecularly characterized QTLs [17]. However, these studies used lab strains of maize, and it remains to be tested how such alleles will perform in elite varieties.

5.4. Case 4: Uncovering Conserved Gene Functions and Engineering Quantitative Trait Variation by CRISPR-Cas9 Cis-Regulatory Mutations in the Tomato CLV-WUS Pathway

Besides the random-promoters mutagenesis by CRISPR to screen beneficial alleles in cereal crops $[17,20]$, two studies conducted precise editing of predicted cis-regulatory sequences in tomato. Loss of tomato SlCLV3 results in enlarged meristems that cause fasciated phenotypes. Wang et al. used CRISPR to precisely edit the CNSs in SICLV3 and SIWUS promoters and studied the functional relationships of cis-regulatory sequences in 
their promoters [18]. Two conserved CNSs were found that contained functional sequences and showed additive, synergistic, and redundant relationships to contribute to SlCLV3 promoter function [19]. Unlike the SlCLV3 promoter, the SIWUS promoter is more tolerant to perturbations, as most of its promoter-edited mutants appeared normal $[18,67]$. Besides cis-regulatory interactions, Hendelman et al. revealed that the conserved cis-regulatory sequences of WOX9 are responsible for its pleiotropic activity in embryo and inflorescence development $[19,68]$. The authors used CRISPR to edit these conserved cis-regulatory sequences and obtained a comprehensive promoter-edited allelic series to expose multiple pleiotropic roles of SIWOX9 [19]. Promoter deletions in two separate regions were tightly associated with branched inflorescences and embryonic lethality phenotypes, respectively [19]. These findings suggested precise cis-regulatory region mutagenesis by genome editing can discover hidden conserved pleiotropy [19], which is important for generating beneficial alleles when a negative pleiotropic effect on other traits needs to be limited. Therefore, genome editing tools can be used to dissect the complex cis-regulatory interactions, pleiotropic functions and engineer variants to shape traits quantitatively, which can guide the precise design of cis-regulatory alleles for cereal crop improvement.

\section{Challenges and Emerging Technologies for CRISPR/Cas9-Based Crop Improvement}

After just a little under a decade, CRISPR/Cas9 has revolutionized gene editing capabilities in a wide range of organisms, including cereal crops $[69,70]$. The case studies in the previous section demonstrate the power of CRISPR/Cas9 to modulate gene activity to improve crop yield. Still, several milestones must be reached to make CRISPR a routine tool for crop improvement, including engineering precise edits, stacking mutations, and introducing edits into agriculturally important germplasm. Here, we highlight several recent advances in CRISPR technologies and techniques with a promise to more efficiently deploy gene editing in cereal crops (Figure 2).
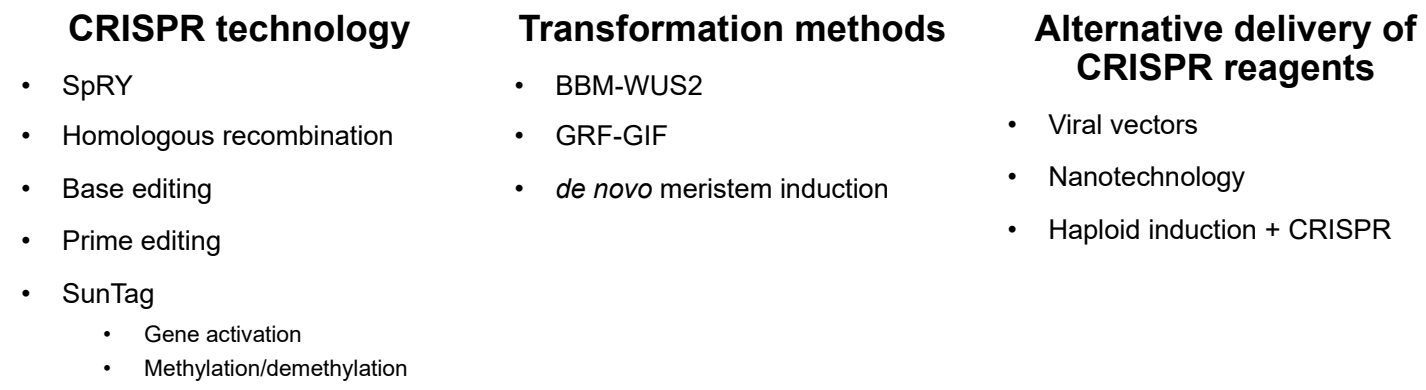

Figure 2. Recent technological advances to facilitate CRISPR/Cas9 editing in cereals. Emerging CRISPR technologies include SpRY, a mutated form of Cas9 with a relaxed PAM requirement; CRISPR base-editing, in which individual base pairs are changed; prime editing, in which a Cas9-nickase is fused to a reverse transcriptase to produce precise knock-in mutations guided by a pegRNA template; homologous recombination, where larger insertions can be introduced into a genomic region of interest; and SunTag gene activation and methylation/demethylation, where a catalytically inactive Cas9 is fused to effectors that modulate gene expression or methylation patterns. CRISPR technology can be delivered into cereals, using improved transformation methods involving developmentally important genes, such as BABYBOOM-WUSCHEL or GROWTH-REGULATING FACTOR 4 and GRF-INTERACTING 1 (GRF-GIF), or through de novo meristem induction. In addition to using stable transformation to enable CRISPR editing, alternative delivery of CRISPR reagents includes the use of viral vectors, nanotechnology, and haploid induction plus CRISPR.

\subsection{CRISPR Techniques}

CRISPR/Cas9 uses the Cas9 enzyme to generate double-stranded breaks in a specific DNA sequence guided by sgRNA molecules that recognize a genomic region of interest. Double-stranded breaks are then repaired via either non-homologous end joining (NHEJ) or homologous recombination (HR). NHEJ is error prone, producing small insertions and deletions in the DNA sequence, generating mutations in regions of interest. Larger deletions and insertions can also be generated at a lower frequency. Most plant systems 
rely on Agrobacterium-mediated or biolistic delivery of a plasmid containing Cas9 under the expression of a constitutive promoter and the sgRNA sequences driven by PollII promoters. An extensive description of CRISPR editing in monocots has recently been reviewed elsewhere [71,72].

To create single base-pair substitutions in a genomic region of interest, for example to change a coding sequence, CRISPR base editing can be used [73]. In this technique, a catalytically inactive Cas9 (dCas9) is coupled to a deaminase to convert one base pair to another. Since this method uses a dead Cas9, the introduction of double-strand breaks and homology-directed repair do not occur, which allows for more precise editing. CRISPR base editing has been successfully applied in many plants, including maize, rice, and wheat [74-77].

Generally, CRISPR target sequences are limited to the NGG protospacer adjacent motif (PAM) when using the Cas9 enzyme. While it is generally possible to select targets with the NGG motif to edit genomic regions of interest, there are instances when a very specific target sequence is desired. Recent work from Ren et al. and Xu et al. relaxed the requirement for a specific PAM sequence, allowing for greater control over choice of region for CRISPR editing [78,79]. This technology, called SpRY, uses a version of Cas9 that has 11 amino acid substitutions to enable CRISPR targeting of any site (NNN), and has been successfully used to edit rice and conifers. A SpRY base editor was also developed and could also edit relaxed target sites. It should be noted, however, that edits in the original sgRNAs transformed into the plants were observed for SpRY, likely a result of the guides editing themselves, which could result in off-target effects.

While CRISPR mutations derived from non-homologous end joining have been widely reported in plants, creating targeted insertions via homologous recombination remains a challenge. However, a more efficient method to select for precise gene insertions into plant genomes has been recently reported. In this method, Cas9 is expressed early during maize transformation, and mobilizes a donor template flanked with HR sites. Excision of the donor template by Cas9 activates a selectable marker gene, resulting in the selection only of transformants that have successfully undergone homologous recombination [80]. Another study used CRISPR/Cas9 to create a site-specific landing pad to insert multiple transgenes into selected sites in the maize genome [81]. Other non-CRISPR-based methods are being developed to precisely deliver transgenes into plants, such as recombineering [82].

An additional method to overcome the imprecise nature of edits derived from NHEJ has been developed $[83,84]$. With this technology, called prime editing, a catalytically impaired Cas9-nickase is fused to a reverse transcriptase (RT). A prime-editing guide RNA (pegRNA) guides the Cas9-RT fusion, and encodes the desired DNA changes. This system can produce precise base-pair changes, as well as small transversions, insertions and deletions in wheat and rice. While initial reports of efficiency for prime editing in plants were low, it was substantially improved by modifying the pegRNA melting temperature [85].

As demonstrated with CRISPR editing of cis-regulatory regions, modulating gene expression can have a beneficial impact on yield. As an alternative to editing the DNA of cis-regulatory regions, CRISPR activation or inactivation can be employed to alter gene expression. This technique also uses dCas9, which is fused with different protein domains to regulate gene expression. For example, the SunTag system can be used to activate gene expression when combined with the transcriptional activator VP64, as well as alter methylation patterns when combined with methylation or demethylation effectors [86-88]. In this system, dCas9 is fused to tandem GCN4 epitopes, bringing them to a specific locus, where they are detected by a GCN4 antibody fused with either the VP64 activator or methylation enzymes. In the cases of the dCas9 fusions with methylation enzymes, induced epigenetic changes were heritable over many generations in the absence of the transgene in Arabidopsis. This suggests the approach could be used to induce changes in expression in crop plants in a non-GMO context. Other protein domains fused to dCas 9 have been reported to have even higher transcriptional activation capabilities than VP64, 
but the degree of activation is gene-dependent, so more work will be needed to understand the underlying mechanisms $[89,90]$.

Beyond modifying Cas9 to generate specific types of edits, predicting the on-target efficiency and off-target effects of particular sgRNAs remains challenging. Recently, however, machine learning approaches have been developed to more efficiently predict these two parameters, and can reduce the guesswork required when designing efficient sgRNAs $[91,92]$.

\subsection{Increasing Transformation Efficiency in Cereals}

Efficient Agrobacterium-mediated or biolistic transformation of cereal crops is restricted to specific species and cultivars [93-95]. As a result, it is essential to develop new technologies to increase transformation efficiency for CRISPR mutagenesis of recalcitrant crop germplasm.

One effort to improve transformation efficiency has involved ectopically expressing developmental (DEV) genes necessary for embryogenesis and meristem formation, including those encoding the maize embryonic transcription factor BABYBOOM (BBM) and meristematic transcription factor ZmWUSCHEL2 (ZmWUS2) to improve transgenic tissue regeneration [96-98]. Agrobacterium-mediated delivery of a cassette driving overexpression of both of these genes into recalcitrant lines of maize, rice, sugarcane, and sorghum resulted in increased transformation efficiency. These methods have expanded the number of maize varieties amenable to transformation, with varying degrees of success, but expression of the DEV genes must be tightly regulated, because ectopic expression results in growth defects.

A more recent advance in plant transformation uses a transcription factor chimera, consisting of wheat meristem regulators GROWTH-REGULATING FACTOR 4 and GRFINTERACTING 1 (GRF-GIF), to increase both regeneration efficiency and speed [99]. This has resulted in a more efficient transformation of wheat (up to approximately $80 \%$ ), rice, and triticale. It has also expanded the number of wheat cultivars amenable to transformation, including bread and durum wheat lines. Overexpression of maize GRF5, a homolog of wheat GRF1, also increased transformation efficiency in the maize A188 line, suggesting the GRF-GIF chimera may further increase transformation efficiency in this crop plant [100]. The efficiency of the GRF-GIF system appears to be limited to specific genes within the GRF family, as a higher transformation efficiency was reported in maize when using maize GRF5, but not the Arabidopsis ortholog. Furthermore, while the wheat GRF-GIF chimera could successfully increase rice transformation efficiency, this system may need to be fine-tuned on a per species basis to achieve the same boosts seen in wheat transformation. Debernardi et al. postulate that because GRF-GIF and BBM-WUS act at different stages of meristem differentiation and proliferation, the two technologies could be combined to synergistically enhance overall transformation efficiency.

A third transformation strategy is to deliver CRISPR transgenes into de novo induced meristematic tissue, instead of transforming callus generated from explants [101]. In one such study, axillary shoot meristems were removed from Cas9-expressing N. benthamiana plants, which were then treated with Agrobacterium strains expressing developmental regulators, a luciferase reporter to assess transformation efficiency, and a sgRNA targeting PHYTOENE DESATURASE to allow visual assessment of CRISPR-editing efficiency. Ectopic expression of the developmental regulators SHOOT MERISTEMLESS (STM) and ZmWUS2, or ZmWUS2 and Agrobacterium tumor-inducing gene isopentenyl transferase (ipt), produced de novo meristems, which eventually formed flowers that produced seeds with edits generated from the sgRNA. So far, this strategy has only been successful in dicots, but if it can be extended to cereals, it will greatly accelerate the production of CRISPR mutations. Indeed, particle bombardment of wheat shoot meristems can produce transformants, indicating that this technique could be applied to cereals [102]. 


\subsection{Use of Viral Vectors for CRISPR Mutagenesis}

In addition to improving existing plant-transformation technologies, viral vectors are being explored as an alternative to deliver CRISPR reagents into plants. When Cas 9 transgenic plants were infected with RNA viruses engineered with sgRNAs tagged with the Flowering Locus T (FT) mobile RNA element, they successfully edited germline cells at high frequency [103]. Thus, with a single transgenic line, multiple guide RNAs can be delivered, greatly reducing the number of stable transformants needed for CRISPR. Viral vectors are generally limited by insert size, but a plant RNA rhabdovirus was engineered to harbor both Cas9 and sgRNAs and successfully edited Nicotiana benthamiana plants [104]. While so far demonstrated only in this species, these methods may be extended for cereal crop gene editing. For example, the foxtail mosaic virus (FoMV) was used to transiently express transgenes and deliver a sgRNA into Setaria viridis, Nicotiana benthamiana, and maize [105]. Future work should explore the most appropriate viral vectors and mobile RNA elements to maximize editing efficiency in germline tissues of cereals for heritable mutations.

\subsection{Haploid Induction Plus CRISPR to Introgress into Elite Varieties}

Introgressing a favorable allele into a commercial maize inbred line requires at least six generations of backcrossing to recreate the inbred background. Haploid induction followed by chromosomal doubling is a routine technique to rapidly generate inbred lines for use in developing hybrid maize varieties [106]. Haploids can be generated by crossing plants using pollen from matrilineal/not like dad/ZmphospholipaseA1 ( $\mathrm{mtl} /$ nld/Zmpla1) mutants via a poorly understood mechanism [107-109]. Work from Kelliher et al. demonstrated the efficacy of combining CRISPR with the $m t l$ haploid inducer in maize, editing the yield-related genes GRAIN WEIGHT 2 (GW2) GW2-1 and GW2-2, as well as VRS1-LIKE HOMEOBOX PROTEIN (VLHP1) and VLHP2, in several elite lines of maize [110]. Another group successfully edited LIGULELESS1 (LG1) and UB2 in the maize B73 inbred line with a related haploid inducer line containing CRISPR/Cas9 [111]. Remarkably, durum wheat was also edited by using interspecies crosses of haploid inducing maize pollen carrying CRISPR/Cas9 onto wheat [112]. As an alternative to mtl-based haploid induction, centromeric histone H3 (cenh3) heterozygous maize mutants can also induce haploids at levels up to $20 \%$, so this system could also be combined with CRISPR/Cas9 to quickly produce edited plants in a wide array of germplasm and bypass transformation [113]. Haploid induction strategies assisted with seed-specific marker lines will help improve the efficiency of identifying CRISPR-edited plants with this technique to be able to rapidly identify haploids at the seed stage [114,115].

Here we have highlighted just a few exciting technological advances in delivering CRISPR gene editing to crop plants. Other emerging methods include nanotechnologybased delivery of CRISPR reagents, transient expression of transgenes by spraying viral or Agrobacterium nanoparticles, and machine learning algorithms for improving stable transformation [116-121]. Combining several of these methods will likely allow for increased editing and introgression of CRISPR alleles into cereal crops, including agriculturally important germplasm.

\section{Future Prospects}

Most crop genome editing and evaluation of yield-related traits has not been in commercial elite lines $[17,20]$. However, a weak $C L V$ allele was recently found to increase yield up to $28 \%$ in elite hybrids in Vietnam [122]. This suggests great potential for application of genome-edited alleles in commercial varieties. A recent study integrated multiplexed CRISPR/Cas9-based high-throughput targeted mutagenesis with genetic mapping and genomic approaches to successfully target 743 candidate genes, indicating that genome editing has advanced to a high-throughput stage [123]. This review focused on knowledge of inflorescence yield-related traits in cereal crops, including key developmental regulatory genes. It is becoming clear that quantitative variation of yield-related traits can be success- 
fully engineered by editing of developmental genes, suggesting that crop breeding does not need to depend on naturally occurring mutations. Instead, artificially generated variation can be the raw material for future breeding. With advances in genome-editing technologies and the increasing understanding of biological traits, knowledge-driven breeding by design is becoming a reality that can be deployed to improve the grain yield of current elite inbred lines and to domesticate wild ancestors de novo to recreate new crop varieties [124]. These versatile technologies will allow us to generate diverse germplasm for a growing population and engineer more resilient crops under changing climate conditions.

Author Contributions: L.L. and P.L.L. equally contributed to the work. L.L., P.L.L. and D.J. co-write the manuscript. All authors have read and agreed to the published version of the manuscript.

Funding: Funding provided by the National Science Foundation (IOS-1546837) to D.J., as well as NSF Postdoctoral Research Fellowships in Biology Program under grant number 2010642 to P.L.L.

Institutional Review Board Statement: Not applicable.

Informed Consent Statement: Not applicable.

Data Availability Statement: The review did not report any data.

Acknowledgments: We acknowledge Munenori Kitagawa for providing helpful comments about the manuscript.

Conflicts of Interest: The authors declare no conflict of interest.

\section{References}

1. Ross-Ibarra, J.; Morrell, P.L.; Gaut, B.S. Plant Domestication, a Unique Opportunity to Identify the Genetic Basis of Adaptation. Proc. Natl. Acad. Sci. USA 2007, 104 (Suppl. S1), 8641-8648. [CrossRef]

2. Yu, H.; Li, J. Short- and Long-Term Challenges in Crop Breeding. Natl. Sci. Rev. 2021, 8. [CrossRef]

3. Smýkal, P.; Nelson, M.N.; Berger, J.D.; Von Wettberg, E.J.B. The Impact of Genetic Changes during Crop Domestication. Agronomy 2018, 8, 119. [CrossRef]

4. Fernie, A.R.; Yan, J. De Novo Domestication: An Alternative Route toward New Crops for the Future. Mol. Plant 2019, 12, 615-631. [CrossRef]

5. Baenziger, P.S.; Russell, W.K.; Graef, G.L.; Campbell, B.T. Improving Lives: 50 Years of Crop Breeding, Genetics, and Cytology (C-1). Crop Sci. 2006, 46, 2230-2244. [CrossRef]

6. Lee, E.A.; Tracy, W.F. Modern Maize Breeding. Handb. Maize Genet. Genomics 2009, II, 141-160. [CrossRef]

7. Brown, P.J.; Upadyayula, N.; Mahone, G.S.; Tian, F.; Bradbury, P.J.; Myles, S.; Holland, J.B.; Flint-garcia, S.; Mcmullen, M.D.; Buckler, E.S.; et al. Distinct Genetic Architectures for Male and Female Inflorescence Traits of Maize. PLoS Genet. 2011, 7, e1002383. [CrossRef] [PubMed]

8. Liu, L.; Du, Y.; Huo, D.; Wang, M.; Shen, X.; Yue, B.; Qiu, F.; Zheng, Y.; Yan, J.; Zhang, Z. Genetic Architecture of Maize Kernel Row Number and Whole Genome Prediction. Theor. Appl. Genet. 2015, 128. [CrossRef]

9. Xiao, Y.; Tong, H.; Yang, X.; Xu, S.; Pan, Q.; Qiao, F.; Raihan, M.S.; Luo, Y.; Liu, H.; Zhang, X.; et al. Genome-Wide Dissection of the Maize Ear Genetic Architecture Using Multiple Populations. New Phytol. 2016, 210, 1095-1106. [CrossRef]

10. Li, M.; Zhong, W.; Yang, F.; Zhang, Z. Genetic and Molecular Mechanisms of Quantitative Trait Loci Controlling Maize Inflorescence Architecture. Plant Cell Physiol. 2018, 59, 448-457. [CrossRef]

11. Xing, Y.; Zhang, Q. Genetic and Molecular Bases of Rice Yield. Annu. Rev. Plant Biol. 2010, 61, 421-442. [CrossRef]

12. Wang, Y.; Li, J. Branching in Rice. Curr. Opin. Plant Biol. 2011, 14, 94-99. [CrossRef]

13. Tu, C.; Li, T.; Liu, X. Genetic and Epigenetic Regulatory Mechanism of Rice Panicle Development. AIP Conf. Proc. 2019, 2079. [CrossRef]

14. Gao, X.Q.; Wang, N.; Wang, X.L.; Zhang, X.S. Architecture of Wheat Inflorescence: Insights from Rice. Trends Plant Sci. 2019, 24, 802-809. [CrossRef]

15. Tanaka, W.; Pautler, M.; Jackson, D.; Hirano, H.-Y. Grass Meristems II-Inflorescence Architecture, Flower Development and Meristem Fate. Plant Cell Physiol. 2013, 54, 313-324. [CrossRef] [PubMed]

16. Rodríguez-Leal, D.; Lemmon, Z.H.; Man, J.; Bartlett, M.E.; Lippman, Z.B. Engineering Quantitative Trait Variation for Crop Improvement by Genome Editing. Cell 2017, 171, 470-480.e8. [CrossRef] [PubMed]

17. Liu, L.; Gallagher, J.; Arevalo, E.D.; Chen, R.; Skopelitis, T.; Wu, Q.; Bartlett, M.; Jackson, D. Enhancing Grain-Yield-Related Traits by CRISPR-Cas9 Promoter Editing of Maize CLE Genes. Nat. Plants 2021, 7, 287-294. [CrossRef]

18. Wang, X.; Aguirre, L.; Rodríguez-leal, D.; Hendelman, A. Dissecting Cis- Regulatory Control of Quantitative Trait Variation in a Plant Stem Cell Circuit. Nat. Plants 2021, 7, 419-427. [CrossRef] [PubMed] 
19. Hendelman, A.; Zebell, S.; Rodriguez-leal, D.; Eshed, Y.; Efroni, I.; Lippman, Z.B.; Hendelman, A.; Zebell, S.; Rodriguez-leal, D.; Dukler, N.; et al. Conserved Pleiotropy of an Ancient Plant Homeobox Gene Uncovered by Cis- Regulatory Dissection Article Conserved Pleiotropy of an Ancient Plant Homeobox Gene Uncovered by Cis- Regulatory Dissection. Cell 2021. [CrossRef]

20. Cui, Y.; Hu, X.; Liang, G.; Feng, A.; Wang, F.; Ruan, S.; Dong, G.; Shen, L.; Zhang, B.; Chen, D.; et al. Production of Novel Beneficial Alleles of a Rice Yield-related QTL by CRISPR/Cas9. Plant Biotechnol. J. 2020. [CrossRef]

21. Kellogg, E.A. Beyond taxonomy: Prospects for understanding morphological diversity in the gras-ses (Poaceae). Darwiniana 2006, $44,7-17$.

22. Bommert, P.; Whipple, C. Grass Inflorescence Architecture and Meristem Determinacy. Semin. Cell Dev. Biol. 2018, 79, 37-47. [CrossRef] [PubMed]

23. Williams, L.; Fletcher, J.C. Stem Cell Regulation in the Arabidopsis Shoot Apical Meristem. Curr. Opin. Plant Biol. 2005, 8, 582-586. [CrossRef]

24. Wu, Q.; Xu, F.; Jackson, D. All Together Now, a Magical Mystery Tour of the Maize Shoot Meristem. Curr. Opin. Plant Biol. 2018, 45, 26-35. [CrossRef] [PubMed]

25. Clark, S.E.; Williams, R.W.; Meyerowitz, E.M. The CLAVATA1 Gene Encodes a Putative Receptor Kinase That Controls Shoot and Floral Meristem Size in Arabidopsis. Cell 1997, 62, 575-585. [CrossRef]

26. Fletcher, J.C. Signaling of Cell Fate Decisions by CLAVATA3 in Arabidopsis Shoot Meristems. Science 1999, 283, 1911-1914. [CrossRef]

27. Jeong, S.; Trotochaud, A.E.; Clark, S.E. The Arabidopsis CLAVATA2 Gene Encodes a Receptor-like Protein Required for the Stability of the CLAVATA1 Receptor-like Kinase. Plant Cell 1999, 11, 1925-1933. [CrossRef]

28. Brand, U.; Fletcher, J.C.; Hobe, M.; Meyerowitz, E.M.; Simon, R. Dependence of Stem Cell Fate in Arabidopsis on a Feedback Loop Regulated by CLV3 Activity. Science 2000, 289, 617-619. [CrossRef]

29. Schoof, H.; Lenhard, M.; Haecker, A.; Mayer, K.F.X.; Jürgens, G.; Laux, T. The Stem Cell Population of Arabidopsis Shoot Meristems Is Maintained by a Regulatory Loop between the CLAVATA and WUSCHEL Genes. Cell 2000, 100, 635-644. [CrossRef]

30. Bommert, P.; Lunde, C.; Nardmann, J.; Vollbrecht, E.; Running, M.; Jackson, D.; Hake, S.; Werr, W. Thick Tassel Dwarf1 Encodes a Putative Maize Ortholog of the Arabidopsis CLAVATA1 Leucine-Rich Repeat Receptor-like Kinase. Development 2005, 132, 1235-1245. [CrossRef]

31. Rodriguez-Leal, D.; Xu, C.; Kwon, C.T.; Soyars, C.; Demesa-Arevalo, E.; Man, J.; Liu, L.; Lemmon, Z.H.; Jones, D.S.; Van Eck, J.; et al. Evolution of Buffering in a Genetic Circuit Controlling Plant Stem Cell Proliferation. Nat. Genet. 2019, 51, 786-792. [CrossRef] [PubMed]

32. Tran, Q.H.; Bui, N.H.; Kappel, C.; Dau, N.T.N.; Nguyen, L.T.; Tran, T.T.; Khanh, T.D.; Trung, K.H.; Lenhard, M.; Vi, S.L. Mapping-by-Sequencing via MutMap Identifies a Mutation in ZmCLE7 Underlying Fasciation in a Newly Developed EMS Mutant Population in an Elite Tropical Maize Inbred. Genes 2020, 11, 281. [CrossRef]

33. Je, B.I.; Gruel, J.; Lee, Y.K.; Bommert, P.; Arevalo, E.D.; Eveland, A.L.; Wu, Q.; Goldshmidt, A.; Meeley, R.; Bartlett, M.; et al. Signaling from Maize Organ Primordia via FASCIATED EAR3 Regulates Stem Cell Proliferation and Yield Traits. Nat. Genet. 2016, 48, 785-791. [CrossRef] [PubMed]

34. Bommert, P.; Je, B.I.; Goldshmidt, A.; Jackson, D. The Maize G $\alpha$ Gene COMPACT PLANT2 Functions in CLAVATA Signalling to Control Shoot Meristem Size. Nature 2013, 502, 555-558. [CrossRef] [PubMed]

35. Wu, Q.; Xu, F.; Liu, L.; Char, S.N.; Ding, Y.; Je, B.I.; Schmelz, E.; Yang, B.; Jackson, D. The Maize Heterotrimeric G Protein $\beta$ Subunit Controls Shoot Meristem Development and Immune Responses. Proc. Natl. Acad. Sci. USA 2020, 117, 1799-1805. [CrossRef]

36. Je, B.I.; Xu, F.; Wu, Q.; Liu, L.; Meeley, R.; Gallagher, J.P.; Corcilius, L.; Payne, R.J.; Bartlett, M.E.; Jackson, D. The Clavata Receptor Fasciated Ear2 Responds to Distinct Cle Peptides by Signaling through Two Downstream Effectors. Elife 2018, 7. [CrossRef]

37. Bommert, P.; Nagasawa, N.S.; Jackson, D. Quantitative Variation in Maize Kernel Row Number Is Controlled by the FASCIATED EAR2 Locus. Nat. Genet. 2013, 45, 334-337. [CrossRef]

38. Tanaka, W.; Hirano, H.-Y. Antagonistic Action of TILLERS ABSENT1 and FLORAL ORGAN NUMBER2 Regulates Stem Cell Maintenance during Axillary Meristem Development in Rice. New Phytol. 2020, 225, 974-984. [CrossRef] [PubMed]

39. Suzaki, T.; Sato, M.; Ashikari, M.; Miyoshi, M.; Nagato, Y.; Hirano, H.Y. The Gene FLORAL ORGAN NUMBER1 Regulates Floral Meristem Size in Rice and Encodes a Leucine-Rich Repeat Receptor Kinase Orthologous to Arabidopsis CLAVATA1. Development 2004, 131, 5649-5657. [CrossRef]

40. Huang, X.; Qian, Q.; Liu, Z.; Sun, H.; He, S.; Luo, D.; Xia, G.; Chu, C.; Li, J.; Fu, X. Natural Variation at the DEP1 Locus Enhances Grain Yield in Rice. Nat. Genet. 2009, 41. [CrossRef]

41. Sun, H.; Qian, Q.; Wu, K.; Luo, J.; Wang, S.; Zhang, C.; Ma, Y.; Liu, Q.; Huang, X.; Yuan, Q.; et al. Heterotrimeric G Proteins Regulate Nitrogen-Use Efficiency in Rice. Nat. Genet. 2014, 46, 652-656. [CrossRef]

42. Studer, A.; Zhao, Q.; Ross-Ibarra, J.; Doebley, J. Identification of a Functional Transposon Insertion in the Maize Domestication Gene Tb1. Nat. Genet. 2011, 43,1-6. [CrossRef]

43. Dong, Z.; Xiao, Y.; Govindarajulu, R.; Feil, R.; Siddoway, M.L.; Nielsen, T.; Lunn, J.E.; Hawkins, J.; Whipple, C.; Chuck, G. The Regulatory Landscape of a Core Maize Domestication Module Controlling Bud Dormancy and Growth Repression. Nat. Commun. 2019, 10. [CrossRef] [PubMed]

44. Takeda, T.; Suwa, Y.; Suzuki, M.; Kitano, H.; Ueguchi-Tanaka, M.; Ashikari, M.; Matsuoka, M.; Ueguchi, C. The OsTB1 Gene Negatively Regulates Lateral Branching in Rice. Plant J. 2003, 33, 513-520. [CrossRef] 
45. Dixon, L.E.; Greenwood, J.R.; Bencivenga, S.; Zhang, P.; Cockram, J.; Mellers, G.; Ramm, K.; Cavanagh, C.; Swain, S.M.; Boden, S.A. TEOSINTE BRANCHED1 Regulates Inflorescence Architecture and Development in Bread Wheat (Triticum Aestivum). Plant Cell 2018, 30, 563-581. [CrossRef] [PubMed]

46. Jiao, Y.; Wang, Y.; Xue, D.; Wang, J.; Yan, M.; Liu, G.; Dong, G.; Zeng, D.; Lu, Z.; Zhu, X.; et al. Regulation of OsSPL14 by OsmiR156 Defines Ideal Plant Architecture in Rice. Nat. Genet. 2010, 42, 541-545. [CrossRef] [PubMed]

47. Miura, K.; Ikeda, M.; Matsubara, A.; Song, X.; Ito, M.; Asano, K.; Matsuoka, M. OsSPL14 Promotes Panicle Branching and Higher Grain Productivity in Rice. Nat. Genet. 2010, 42, 545-549. [CrossRef] [PubMed]

48. Lu, Z.; Yu, H.; Xiong, G.; Wang, J.; Jiao, Y.; Liu, G.; Jing, Y.; Meng, X.; Hu, X.; Qian, Q.; et al. Genome-Wide Binding Analysis of the Transcription Activator Ideal Plant Architecture1 Reveals a Complex Network Regulating Rice Plant Architecture. Plant Cell 2013, 25, 3743-3759. [CrossRef] [PubMed]

49. Song, X.; Lu, Z.; Yu, H.; Shao, G.; Xiong, J.; Meng, X.; Jing, Y.; Liu, G.; Xiong, G.; Duan, J.; et al. IPA1 Functions as a Downstream Transcription Factor Repressed by D53 in Strigolactone Signaling in Rice. Cell Res. 2017, 27, 1128-1141. [CrossRef]

50. Wang, L.; Sun, S.; Jin, J.; Fu, D.; Yang, X.; Weng, X.; Xu, C.; Li, X.; Xiao, J.; Zhang, Q. Coordinated Regulation of Vegetative and Reproductive Branching in Rice. Proc. Natl. Acad. Sci. USA 2015. [CrossRef]

51. Chuck, G.S.; Brown, P.J.; Meeley, R.; Hake, S. Maize SBP-Box Transcription Factors Unbranched2 and Unbranched3 Affect Yield Traits by Regulating the Rate of Lateral Primordia Initiation. Proc. Natl. Acad. Sci. USA 2014, 111, 18775-18780. [CrossRef]

52. Liu, L.; Du, Y.; Shen, X.; Li, M.; Sun, W.; Huang, J.; Liu, Z.; Tao, Y.; Zheng, Y.; Yan, J.; et al. KRN4 Controls Quantitative Variation in Maize Kernel Row Number. PLoS Genet. 2015, 11, e1005670. [CrossRef]

53. Du, Y.; Liu, L.; Peng, Y.; Li, M.; Li, Y.; Liu, D.; Li, X.; Zhang, Z. Unbranched3 Expression and Inflorescence Development Is Mediated by Unbranched2 and the Distal Enhancer, KRN4, in Maize. PLoS Genet. 2020, 16, e1008764. [CrossRef] [PubMed]

54. Du, Y.; Liu, L.; Li, M.; Fang, S.; Shen, X.; Chu, J.; Zhang, Z. UNBRANCHED3 Regulates Branching by Modulating Cytokinin Biosynthesis and Signaling in Maize and Rice. New Phytol. 2017, 214. [CrossRef] [PubMed]

55. Liu, J.; Cheng, X.; Liu, P.; Sun, J. MiR156-Targeted SBP-Box Transcription Factors Interact with DWARF53 to Regulate Teosinte Branched1 and Barren STALK1 Expression in Bread Wheat. Plant Physiol. 2017, 174, 1931-1948. [CrossRef] [PubMed]

56. Lundqvist, U.; Lundqvist, A. The Co-Operation between Intermedium Genes and the Six-Row Gene Hex-v in a Six-Row Variety of Barley. Hereditas 1989, 110, 227-233. [CrossRef]

57. Ramsay, L.; Comadran, J.; Druka, A.; Marshall, D.F.; Thomas, W.T.B.; MacAulay, M.; MacKenzie, K.; Simpson, C.; Fuller, J.; Bonar N.; et al. INTERMEDIUM-C, a Modifier of Lateral Spikelet Fertility in Barley, Is an Ortholog of the Maize Domestication Gene TEOSINTE BRANCHED 1. Nat. Genet. 2011, 43, 169-172. [CrossRef]

58. Komatsuda, T.; Pourkheirandish, M.; He, C.; Azhaguvel, P.; Kanamori, K.; Perovic, D.; Stein, N.; Graner, A.; Wicker, T.; Tagiri, A.; et al. Six-Rowed Barley Originated from a Mutation in a Homeodomain-Leucine Zipper I-Class Homeobox Gene. Proc. Natl. Acad. Sci. USA 2007, 104, 1424-1429. [CrossRef]

59. Youssef, H.M.; Eggert, K.; Koppolu, R.; Alqudah, A.M.; Poursarebani, N.; Fazeli, A.; Sakuma, S.; Tagiri, A.; Rutten, T.; Govind, G.; et al. VRS2 Regulates Hormone-Mediated Inflorescence Patterning in Barley. Nat. Genet. 2017, 49, 157-161. [CrossRef]

60. van Esse, G.W.; Walla, A.; Finke, A.; Koornneef, M.; Pecinka, A.; von Korff, M. Six-Rowed Spike3 (VRS3) Is a Histone Demethylase That Controls Lateral Spikelet Development in Barley. Plant Physiol. 2017, 174, 2397-2408. [CrossRef] [PubMed]

61. Koppolu, R.; Anwar, N.; Sakuma, S.; Tagiri, A.; Lundqvist, U.; Pourkheirandish, M.; Rutten, T.; Seiler, C.; Himmelbach, A.; Ariyadasa, R.; et al. Six-Rowed Spike4 (Vrs4) Controls Spikelet Determinacy and Row-Type in Barley. Proc. Natl. Acad. Sci. USA 2013, 4. [CrossRef]

62. Zwirek, M.; Waugh, R.; McKim, S.M. Interaction between Row-Type Genes in Barley Controls Meristem Determinacy and Reveals Novel Routes to Improved Grain. New Phytol. 2019, 221, 1950-1965. [CrossRef]

63. Whipple, C.J.; Kebrom, T.H.; Weber, A.L.; Yang, F.; Hall, D.; Meeley, R.; Schmidt, R.; Doebley, J.; Brutnell, T.P.; Jackson, D.P. Grassy Tillers1 Promotes Apical Dominance in Maize and Responds To Shade Signals in the Grasses. Proc. Natl. Acad. Sci. USA 2011, 108, E506-E512. [CrossRef]

64. Wills, D.M.; Whipple, C.J.; Takuno, S.; Kursel, L.E.; Shannon, L.M.; Ross-Ibarra, J.; Doebley, J.F. From Many, One: Genetic Control of Prolificacy during Maize Domestication. PLoS Genet. 2013, 9, e1003604. [CrossRef] [PubMed]

65. Bortiri, E.; Chuck, G.; Vollbrecht, E.; Rocheford, T.; Martienssen, R.; Hake, S. Ramosa2 Encodes a LATERAL ORGAN BOUNDARY Domain Protein That Determines the Fate of Stem Cells in Branch Meristems of Maize. Plant Cell 2006, 18, 574-585. [CrossRef]

66. Li, M.; Li, X.; Zhou, Z.; Wu, P.; Fang, M.; Pan, X.; Lin, Q.; Luo, W.; Wu, G.; Li, H. Reassessment of the Four Yield-Related Genes Gn1a, DEP1, GS3, and IPA1 in Rice Using a CRISPR/Cas9 System. Front. Plant Sci. 2016, 7, 1-13. [CrossRef]

67. Lippman, Z.B.; Cohen, O.; Alvarez, J.P.; Abu-Abied, M.; Pekker, I.; Paran, I.; Eshed, Y.; Zamir, D. The Making of a Compound Inflorescence in Tomato and Related Nightshades. PLoS Biol. 2008, 6, 2424-2435. [CrossRef] [PubMed]

68. Breuninger, H.; Rikirsch, E.; Hermann, M.; Ueda, M.; Laux, T. Differential Expression of WOX Genes Mediates Apical-Basal Axis Formation in the Arabidopsis Embryo. Dev. Cell 2008, 14, 867-876. [CrossRef] [PubMed]

69. Jinek, M.; Chylinski, K.; Fonfara, I.; Hauer, M.; Doudna, J.A.; Charpentier, E. A Programmable Dual RNA-Guided DNA Endonuclease in Adaptive Bacterial Immunity. Science 2012, 337, 816-821. [CrossRef] [PubMed]

70. Zhu, C.; Bortesi, L.; Baysal, C.; Twyman, R.M.; Fischer, R.; Capell, T.; Schillberg, S.; Christou, P. Characteristics of Genome Editing Mutations in Cereal Crops. Trends Plant Sci. 2017, 22, 38-52. [CrossRef] 
71. Huang, X.; Hilscher, J.; Stoger, E.; Christou, P.; Zhu, C. Modification of Cereal Plant Architecture by Genome Editing to Improve Yields. Plant Cell Rep. 2021. [CrossRef]

72. Nuccio, M.L.; Claeys, H.; Heyndrickx, K.S. CRISPR-Cas Technology in Corn: A New Key to Unlock Genetic Knowledge and Create Novel Products. Mol. Breed. 2021, 41, 11. [CrossRef]

73. Molla, K.A.; Yang, Y. CRISPR/Cas-Mediated Base Editing: Technical Considerations and Practical Applications. Trends Biotechnol. 2019, 37, 1121-1142. [CrossRef]

74. Li, C.; Zong, Y.; Wang, Y.; Jin, S.; Zhang, D.; Song, Q.; Zhang, R.; Gao, C. Expanded Base Editing in Rice and Wheat Using a Cas9-Adenosine Deaminase Fusion. Genome Biol. 2018, 19, 59. [CrossRef]

75. Li, J.; Sun, Y.; Du, J.; Zhao, Y.; Xia, L. Generation of Targeted Point Mutations in Rice by a Modified CRISPR/Cas9 System. Mol. Plant 2017, 10, 526-529. [CrossRef] [PubMed]

76. Lu, Y.; Zhu, J.-K. Precise Editing of a Target Base in the Rice Genome Using a Modified CRISPR/Cas9 System. Mol. Plant 2017, 10, 523-525. [CrossRef]

77. Zong, Y.; Wang, Y.; Li, C.; Zhang, R.; Chen, K.; Ran, Y.; Qiu, J.-L.; Wang, D.; Gao, C. Precise Base Editing in Rice, Wheat and Maize with a Cas9-Cytidine Deaminase Fusion. Nat. Biotechnol. 2017, 35, 438-440. [CrossRef]

78. Ren, Q.; Sretenovic, S.; Liu, S.; Tang, X.; Huang, L.; He, Y.; Liu, L.; Guo, Y.; Zhong, Z.; Liu, G.; et al. PAM-Less Plant Genome Editing Using a CRISPR-SpRY Toolbox. Nat. Plants 2021, 7, 25-33. [CrossRef]

79. Xu, Z.; Kuang, Y.; Ren, B.; Yan, D.; Yan, F.; Spetz, C.; Sun, W.; Wang, G.; Zhou, X.; Zhou, H. SpRY Greatly Expands the Genome Editing Scope in Rice with Highly Flexible PAM Recognition. Genome Biol. 2021, 22, 6. [CrossRef]

80. Barone, P.; Wu, E.; Lenderts, B.; Anand, A.; Gordon-Kamm, W.; Svitashev, S.; Kumar, S. Efficient Gene Targeting in Maize Using Inducible CRISPR-Cas9 and Marker-Free Donor Template. Mol. Plant 2020, 13, 1219-1227. [CrossRef] [PubMed]

81. Gao, H.; Mutti, J.; Young, J.K.; Yang, M.; Schroder, M.; Lenderts, B.; Wang, L.; Peterson, D.; St. Clair, G.; Jones, S.; et al. Complex Trait Loci in Maize Enabled by CRISPR-Cas9 Mediated Gene Insertion. Front. Plant Sci. 2020, 11. [CrossRef]

82. Brumos, J.; Zhao, C.; Gong, Y.; Soriano, D.; Patel, A.P.; Perez-Amador, M.A.; Stepanova, A.N.; Alonso, J.M. An Improved Recombineering Toolset for Plants. Plant Cell 2020, 32, 100-122. [CrossRef]

83. Anzalone, A.V.; Randolph, P.B.; Davis, J.R.; Sousa, A.A.; Koblan, L.W.; Levy, J.M.; Chen, P.J.; Wilson, C.; Newby, G.A.; Raguram, A.; et al. Search-and-Replace Genome Editing without Double-Strand Breaks or Donor DNA. Nature 2019, 576, 149-157. [CrossRef] [PubMed]

84. Lin, Q.; Jin, S.; Zong, Y.; Yu, H.; Zhu, Z.; Liu, G.; Kou, L.; Wang, Y.; Qiu, J.-L.; Li, J.; et al. High-Efficiency Prime Editing with Optimized, Paired PegRNAs in Plants. Nat. Biotechnol. 2021,1-5. [CrossRef]

85. Lin, Q.; Zong, Y.; Xue, C.; Wang, S.; Jin, S.; Zhu, Z.; Wang, Y.; Anzalone, A.V.; Raguram, A.; Doman, J.L.; et al. Prime Genome Editing in Rice and Wheat. Nat. Biotechnol. 2020, 38, 582-585. [CrossRef] [PubMed]

86. Gallego-Bartolomé, J.; Gardiner, J.; Liu, W.; Papikian, A.; Ghoshal, B.; Kuo, H.Y.; Zhao, J.M.-C.; Segal, D.J.; Jacobsen, S.E. Targeted DNA Demethylation of the Arabidopsis Genome Using the Human TET1 Catalytic Domain. Proc. Natl. Acad. Sci. USA 2018, 115, E2125-E2134. [CrossRef]

87. Ghoshal, B.; Vong, B.; Picard, C.L.; Feng, S.; Tam, J.M.; Jacobsen, S.E. A Viral Guide RNA Delivery System for CRISPR-Based Transcriptional Activation and Heritable Targeted DNA Demethylation in Arabidopsis Thaliana. PLoS Genet. 2020, 16, e1008983. [CrossRef]

88. Papikian, A.; Liu, W.; Gallego-Bartolomé, J.; Jacobsen, S.E. Site-Specific Manipulation of Arabidopsis Loci Using CRISPR-Cas9 SunTag Systems. Nat. Commun. 2019, 10, 729. [CrossRef]

89. Lowder, L.G.; Zhou, J.; Zhang, Y.; Malzahn, A.; Zhong, Z.; Hsieh, T.-F.; Voytas, D.F.; Zhang, Y.; Qi, Y. Robust Transcriptional Activation in Plants Using Multiplexed CRISPR-Act2.0 and MTALE-Act Systems. Mol. Plant 2018, 11, 245-256. [CrossRef]

90. Selma, S.; Bernabé-Orts, J.M.; Vazquez-Vilar, M.; Diego-Martin, B.; Ajenjo, M.; Garcia-Carpintero, V.; Granell, A.; Orzaez, D. Strong Gene Activation in Plants with Genome-wide Specificity Using a New Orthogonal CRISPR/Cas9-based Programmable Transcriptional Activator. Plant Biotechnol. J. 2019, 17, 1703-1705. [CrossRef] [PubMed]

91. Niu, M.; Lin, Y.; Zou, Q. SgRNACNN: Identifying SgRNA on-Target Activity in Four Crops Using Ensembles of Convolutional Neural Networks. Plant Mol. Biol. 2021, 105, 483-495. [CrossRef]

92. Hesami, M.; Yoosefzadeh Najafabadi, M.; Adamek, K.; Torkamaneh, D.; Jones, A.M.P. Synergizing Off-Target Predictions for In Silico Insights of CENH3 Knockout in Cannabis through CRISPR/Cas. Molecules 2021, 26, 2053. [CrossRef]

93. Hayta, S.; Smedley, M.A.; Demir, S.U.; Blundell, R.; Hinchliffe, A.; Atkinson, N.; Harwood, W.A. An Efficient and Reproducible Agrobacterium-Mediated Transformation Method for Hexaploid Wheat (Triticum Aestivum L.). Plant Methods 2019, 15, 121. [CrossRef] [PubMed]

94. Wang, K.; Liu, H.; Du, L.; Ye, X. Generation of Marker-Free Transgenic Hexaploid Wheat via an Agrobacterium-Mediated Co-Transformation Strategy in Commercial Chinese Wheat Varieties. Plant Biotechnol. J. 2017, 15, 614-623. [CrossRef] [PubMed]

95. Shrawat, A.K.; Lörz, H. Agrobacterium-Mediated Transformation of Cereals: A Promising Approach Crossing Barriers. Plant Biotechnol. J. 2006, 4, 575-603. [CrossRef] [PubMed]

96. Lowe, K.; Wu, E.; Wang, N.; Hoerster, G.; Hastings, C.; Cho, M.-J.; Scelonge, C.; Lenderts, B.; Chamberlin, M.; Cushatt, J.; et al. Morphogenic Regulators Baby Boom and Wuschel Improve Monocot Transformation. Plant Cell 2016, 28, 1998-2015. [CrossRef] [PubMed] 
97. Lowe, K.; La Rota, M.; Hoerster, G.; Hastings, C.; Wang, N.; Chamberlin, M.; Wu, E.; Jones, T.; Gordon-Kamm, W. Rapid Genotype "Independent" Zea Mays L. (Maize) Transformation via Direct Somatic Embryogenesis. In Vitro Cell. Dev. Biol. Plant 2018, 54, 240-252. [CrossRef]

98. Mookkan, M.; Nelson-Vasilchik, K.; Hague, J.; Zhang, Z.J.; Kausch, A.P. Selectable Marker Independent Transformation of Recalcitrant Maize Inbred B73 and Sorghum P898012 Mediated by Morphogenic Regulators BABY BOOM and WUSCHEL2. Plant Cell Rep. 2017, 36, 1477-1491. [CrossRef] [PubMed]

99. Debernardi, J.M.; Tricoli, D.M.; Ercoli, M.F.; Hayta, S.; Ronald, P.; Palatnik, J.F.; Dubcovsky, J. A GRF-GIF Chimeric Protein Improves the Regeneration Efficiency of Transgenic Plants. Nat. Biotechnol. 2020, 38, 1274-1279. [CrossRef]

100. Kong, J.; Martin-Ortigosa, S.; Finer, J.; Orchard, N.; Gunadi, A.; Batts, L.A.; Thakare, D.; Rush, B.; Schmitz, O.; Stuiver, M.; et al. Overexpression of the Transcription Factor GROWTH-REGULATING FACTOR5 Improves Transformation of Dicot and Monocot Species. Front. Plant Sci. 2020, 11, 1389. [CrossRef]

101. Maher, M.F.; Nasti, R.A.; Vollbrecht, M.; Starker, C.G.; Clark, M.D.; Voytas, D.F. Plant Gene Editing through de Novo Induction of Meristems. Nat. Biotechnol. 2020, 38, 84-89. [CrossRef] [PubMed]

102. Hamada, H.; Linghu, Q.; Nagira, Y.; Miki, R.; Taoka, N.; Imai, R. An in Planta Biolistic Method for Stable Wheat Transformation. Sci. Rep. 2017, 7, 11443. [CrossRef] [PubMed]

103. Ellison, E.E.; Nagalakshmi, U.; Gamo, M.E.; Huang, P.; Dinesh-Kumar, S.; Voytas, D.F. Multiplexed Heritable Gene Editing Using RNA Viruses and Mobile Single Guide RNAs. Nat. Plants 2020, 6, 620-624. [CrossRef] [PubMed]

104. Ma, X.; Zhang, X.; Liu, H.; Li, Z. Highly Efficient DNA-Free Plant Genome Editing Using Virally Delivered CRISPR-Cas9. Nat. Plants 2020, 6, 773-779. [CrossRef] [PubMed]

105. Mei, Y.; Beernink, B.M.; Ellison, E.E.; Konečná, E.; Neelakandan, A.K.; Voytas, D.F.; Whitham, S.A. Protein Expression and Gene Editing in Monocots Using Foxtail Mosaic Virus Vectors. Plant Direct 2019, 3. [CrossRef] [PubMed]

106. Meng, D.; Liu, C.; Chen, S.; Jin, W. Haploid Induction and Its Application in Maize Breeding. Mol. Breed. 2021, 41, 20. [CrossRef]

107. Kelliher, T.; Starr, D.; Richbourg, L.; Chintamanani, S.; Delzer, B.; Nuccio, M.L.; Green, J.; Chen, Z.; McCuiston, J.; Wang, W.; et al. MATRILINEAL, a Sperm-Specific Phospholipase, Triggers Maize Haploid Induction. Nature 2017, 542, 105-109. [CrossRef] [PubMed]

108. Gilles, L.M.; Khaled, A.; Laffaire, J.-B.; Chaignon, S.; Gendrot, G.; Laplaige, J.; Bergès, H.; Beydon, G.; Bayle, V.; Barret, P.; et al. Loss of Pollen-Specific Phospholipase NOT LIKE DAD Triggers Gynogenesis in Maize. EMBO J. 2017, 36, 707-717. [CrossRef]

109. Liu, C.; Li, X.; Meng, D.; Zhong, Y.; Chen, C.; Dong, X.; Xu, X.; Chen, B.; Li, W.; Li, L.; et al. A 4-Bp Insertion at ZmPLA1 Encoding a Putative Phospholipase A Generates Haploid Induction in Maize. Mol. Plant 2017, 10, 520-522. [CrossRef]

110. Kelliher, T.; Starr, D.; Su, X.; Tang, G.; Chen, Z.; Carter, J.; Wittich, P.E.; Dong, S.; Green, J.; Burch, E.; et al. One-Step Genome Editing of Elite Crop Germplasm during Haploid Induction. Nat. Biotechnol. 2019, 37, 287-292. [CrossRef]

111. Wang, B.; Zhu, L.; Zhao, B.; Zhao, Y.; Xie, Y.; Zheng, Z.; Li, Y.; Sun, J.; Wang, H. Development of a Haploid-Inducer Mediated Genome Editing System for Accelerating Maize Breeding. Mol. Plant 2019, 12, 597-602. [CrossRef]

112. Budhagatapalli, N.; Halbach, T.; Hiekel, S.; Büchner, H.; Müller, A.E.; Kumlehn, J. Site-Directed Mutagenesis in Bread and Durum Wheat via Pollination by Cas9/Guide RNA-Transgenic Maize Used as Haploidy Inducer. Plant Biotechnol. J. 2020, 18, 2376-2378. [CrossRef]

113. Wang, N.; Gent, J.I.; Dawe, R.K. Haploid Induction by a Maize Cenh3 Null Mutant. Sci. Adv. 2021, 7, eabe2299. [CrossRef] [PubMed]

114. Dong, L.; Li, L.; Liu, C.; Liu, C.; Geng, S.; Li, X.; Huang, C.; Mao, L.; Chen, S.; Xie, C. Genome Editing and Double-Fluorescence Proteins Enable Robust Maternal Haploid Induction and Identification in Maize. Mol. Plant 2018, 11, 1214-1217. [CrossRef] [PubMed]

115. Xu, J.; Yin, Y.; Jian, L.; Han, B.; Chen, Z.; Yan, J.; Liu, X. Seeing Is Believing: A Visualization Toolbox to Enhance Selection Efficiency in Maize Genome Editing. Plant Biotechnol. J. 2021. [CrossRef] [PubMed]

116. Torti, S.; Schlesier, R.; Thümmler, A.; Bartels, D.; Römer, P.; Koch, B.; Werner, S.; Panwar, V.; Kanyuka, K.; von Wirén, N.; et al. Transient Reprogramming of Crop Plants for Agronomic Performance. Nat. Plants 2021, 7, 159-171. [CrossRef] [PubMed]

117. Demirer, G.S.; Silva, T.N.; Jackson, C.T.; Thomas, J.B.; Ehrhardt, D.W.; Rhee, S.Y.; Mortimer, J.C.; Landry, M.P. Nanotechnology to Advance CRISPR-Cas Genetic Engineering of Plants. Nat. Nanotechnol. 2021, 16, 243-250. [CrossRef]

118. Hesami, M.; Jones, A.M.P. Application of Artificial Intelligence Models and Optimization Algorithms in Plant Cell and Tissue Culture. Appl. Microbiol. Biotechnol. 2020, 104, 9449-9485. [CrossRef]

119. Hesami, M.; Alizadeh, M.; Naderi, R.; Tohidfar, M. Forecasting and Optimizing Agrobacterium-Mediated Genetic Transformation via Ensemble Model- Fruit Fly Optimization Algorithm: A Data Mining Approach Using Chrysanthemum Databases. PLoS ONE 2020, 15, e0239901. [CrossRef] [PubMed]

120. Kaur, P.; Gupta, R.C.; Dey, A.; Malik, T.; Pandey, D.K. Optimization of Salicylic Acid and Chitosan Treatment for Bitter Secoiridoid and Xanthone Glycosides Production in Shoot Cultures of Swertia Paniculata Using Response Surface Methodology and Artificial Neural Network. BMC Plant Biol. 2020, 20, 225. [CrossRef]

121. García-Pérez, P.; Lozano-Milo, E.; Landín, M.; Gallego, P.P. Combining Medicinal Plant In Vitro Culture with Machine Learning Technologies for Maximizing the Production of Phenolic Compounds. Antioxidants 2020, 9, 210. [CrossRef] [PubMed] 
122. Trung, K.H.; Tran, Q.H.; Bui, N.H.; Tran, T.T.; Luu, K.Q.; Tran, N.T.T.; Nguyen, L.T.; Nguyen, D.T.N.; Vu, B.D.; Quan, D.T.T.; et al. A Weak Allele of FASCIATED EAR 2 (FEA2) Increases Maize Kernel Row Number (KRN) and Yield in Elite Maize Hybrids. Agronomy 2020, 10, 1774. [CrossRef]

123. Liu, H.-J.; Jian, L.; Xu, J.; Zhang, Q.; Zhang, M.; Jin, M.; Peng, Y.; Yan, J.; Han, B.; Liu, J.; et al. High-Throughput CRISPR/Cas9 Mutagenesis Streamlines Trait Gene Identification in Maize[OPEN]. Plant Cell 2020, 32, 1397-1413. [CrossRef] [PubMed]

124. Yu, H.; Lin, T.; Meng, X.; Du, H.; Zhang, J.; Liu, G.; Chen, M.; Jing, Y.; Kou, L.; Li, X.; et al. A Route to de Novo Domestication of Wild Allotetraploid Rice Article A Route to de Novo Domestication of Wild Allotetraploid Rice. Cell 2021, 184, 1-15. [CrossRef] 